\title{
APPRAISAL ANALYSIS IN FREEDOM WRITERS MOVIE
}

\author{
Nani Hidayati \\ Sultan Agung Islamic University \\ Semarang, Indonesia \\ nani@unissula.ac.id
}

\begin{abstract}
This study attempts to find out conveyed messages in the movie from the realization of the appraisal and narrative structure as well as to describe the use of the Appraisal System to express LaGravenese's (a) Attitudes, (b) Engagement \& (c) Graduation towards the main characters in Freedom Writers movie screenplay. Using both quantitative and qualitative descriptive approach for discourse appraisal system analysis, the result of this study reveals several messages of tolerance, earning respect and trust, honor diversity, and striving for success and trust from the realization of Appraisal and Narrative Structure either in the dialogues or monologues of Freedom Writers' characters. The result from the Appraisal Devices realizing (a) Attitudes reveals that LaGravenese likes to express characters' negative emotion explicitly than implicitly. He likes to express characters' negative capability than other kinds of Judgments. He appreciates the characters using more Negative Value which denotes that in his opinion, they see each other negatively. (b) Engagement used in the screenplay describes that he emphasizes more on characters' denial towards each other's opinion and existence with the use of more Disclaim Heterogloss in the screenplay. (c) Graduation used in the screenplay describes that the use of more Sharpening Focus indicates he emphasizes on characters' category boundary more than scaling of intensity.
\end{abstract}

Keywords: Appraisal devices, attitude, engagement, and graduation.

\section{INTRODUCTION}

Halliday (in Hallliday and Hasan, 1985: 5-11) notes that the way in understanding language lies in the study of text. According to him, text is defined as a semantic unit which consists of words and sentences that are not only made of meanings, but also as social exchange of meanings. As a form of exchange, a text is meaningful because it can be related into interaction among speakers. A study of both spoken and written text can be done through a discourse analysis (James P.G and Michael. H, 2012:1). As Stubbs (1987:1) stated "Discourse Analysis refers to attempts to study the organization of 
language above the sentence or above the clauses and therefore to study larger linguistic units, such as conversational exchanges or written text."

Dealing with Discourse, there are three general social functions that people use language for. These functions are what Matthiessen (1995:85) called as Meta-functions of Language. The terms for each of the functions are the Interpersonal (the resource for enacting roles and relations in dialogic interaction), the Ideational (the resource for construing our experience of the world around us and inside), and the Textual Meta-function (the resource which enables the speaker to present Ideational and Interpersonal meanings as information organized into text that unfolds in context). Then, Martin and Rose (2003:7) developed these three Meta-functions in the Discourse System into five systems. They are Appraisal (negotiating attitude), Ideational (representing experience), Conjunction (connecting event), Identification (tracking people and things), and Periodicity (the rhythm of Discourse).

Appraisal is the only system dealing with Interpersonal Meta-function. Appraisal itself is classified into three interacting domains - 'attitude', 'engagement' and 'graduation'. Attitude is concerned with our feelings, including emotional reactions, judgments of behaviors and evaluation of things. Engagement deals with sourcing attitudes and the play of voices around opinions in discourse. Graduation attends to grading phenomena whereby feelings are amplified and categories blurred. Appraisal has an important role to interpret people's attitudes, engagement and graduation. It relates the power of a text and makes the text meaningful. Consequently, people should feel and understand the ideas of the text, including a movie transcript. A movie script/screenplay writer should always be aware of the appropriate use of Appraisal Devices so that he or she may be successful in negotiating his or her meanings realized in the movie with the watchers. As a movie watcher, on the other hand, he/she should devise him/herself with adequate understanding of and working knowledge about the Appraisal System used in the movie transcript which is being read in order to come to the appropriate understanding and interpretation of the meanings negotiated by the writer through the text. It shows that using Appraisal while producing a 
text in writing would be very important. Therefore, this study analyzed how language which is central in the movie script works to unfold social discourse.

This study is aimed at finding out the conveyed massages in Freedom Writers movie from the realization of Appraisal and Narrative Structure and appraising Richard LaGravenese, the movie script writer's Attitudes, Engagement, and Graduation toward characters in Freedom Writers movie based on Appraisal Devices. Freedom Writers is a movie that is inspired by a "Freedom Writer's Diary: How a Teacher and 150 Teens Used Writing to Change Themselves and the World Around Them" book written by Erin Gruwell which tells a true story about her students at an inner city high school in Long Beach, California that come together after she as a 23-year-old new teacher, comes to teach at their school and finally transform their live.

\section{DISCUSSION}

Based on the characteristics of this study, this research is a combination of quantitative and descriptive, interpretive, synthesized qualitative approach in nature. Both approaches are used to unfold Richard LaGravenese's Attitudes (Affect, Judgment, and Appreciation), Engagement (mono-gloss and hetero-gloss) and Gradation (force and focus) towards the Freedom Writers' movie characters. It is also going to be descriptive, synthesizes and interpretive in the sense that this study is intended to find out the conveyed messages and describe the realization of interpersonal meanings in the movie screenplay story based on Appraisal systems of Martin and Rose (2003) and White (2002).

The object of this study is Richard LaGravenese 's Attitudes (Affect, Judgment, and Appreciation), Engagement (mono-gloss and hetero-gloss) and Graduation (force and focus) towards the Freedom Writers' movie characters. The unit of analysis of this study is chunk which is analyzed using Appraisal Devices. Validity and reliability are gained through Triangulation method.

In analyzing the data, Narrative Plot Structure and Martin and Rose's (2001) and White's (2001) appraisal system devices/tools-kit were applied because these theories are suitable for a written data analysis. Some steps are going to be undertaken: at first, the data are obtained from the Freedom 
Writers movie transcript written by Richard LaGravanese and published by Paramount Picture in 2006 that can be downloaded in http://www.script-orama.com/movie_scripts/f/freedom-writers-script-transcript.html//; after that, the movie transcript is set out in its entry for comprehending the text as a whole. Secondly, the movie transcript is broken down into manageable chunks for the purpose of analysis. For each chunk, there is general analysis. Finally, each chunk is analyzed especially based on Appraisal Devices/Toolskit which is realized in Richard LaGravenese's Attitudes (Affect, Judgment, and Appreciation), Engagement (mono-gloss and hetero-gloss) and Graduation (force and focus) towards the Freedom Writers' movie characters.

This study has two findings as follows:

\section{The Conveyed Messages in Freedom Writers Movie from the Realization of the Appraisal and Narrative Structure.}

There are several messages found in Freedom Writers movie from the realization of Appraisal Stylistic System either in the dialogues or monologues of Freedom Writers' characters. Through good diction, LaGravenese gives the messages of:

a) Tolerance in which it becomes the central issue during the whole part of the movie.

There are many dialogues among each character of Freedom Writers which reflect the importance of being tolerant to each other. For instance at the beginning of the school year, Erin was deeply disturbed by a racial caricature of one of her students that she found being passed around the room. She found that some of the students were passing around a picture of Jamal, one of her black students. It was a caricature of him and the Mexican boys had drawn him with thick lips. Jamal usually acted like a tough person, but when he saw this picture, he began to cry softly. Erin saw this and told the class that their gangs were nothing compared to the greatest gang of all time - the Nazis. She tells them about the Holocaust only to discover that none of them (except Ben) even knows what it is. Other scene which reflects the start of tolerance is that when Erin raises money from her other jobs and takes the students to the Museum of Tolerance. First, however, she goes to Dr. Carl Cohn, the 
superintendent, to ask him for permission because Mrs. Campbell and Mr. Gelford (the Honours teacher) are very displeased with her. Dr. Cohn gives her permission after some hesitation and in the students' sophomore year, and they are taken there. In that part of scene, it shows that Alejandro Santiago as one of Erin's student is especially moved when he learns that the child he has been assigned to during the tour ended up dying in a concentration camp. The students begin taking action. Several of the boys go around the neighborhood at night, disarming the hidden guns. Meanwhile, Erin also buys brand new books for her students, something they rarely receive because the school board thinks it will be a waste of materials. The students are not accustomed to this kind of treatment and they really begin to respect her. Even the toughest students show their soft side and the tolerance among them begin to bloom.

b) Earning respect and trust is reflected mostly in the main actress's action and struggle to win her students' heart.

At first, Erin has difficulty getting anything accomplished. Many of her students have never been shown any respect in the past. Eva and some of the other students tell Erin that they will not just hand her their respect, she must earn it. That was the beginning reason why Erin really wants to make all students change their perspective; she then even struggles to identify with the students and takes on two other jobs - one as a lingerie salesperson and one as a concierge at the local Marriot, in order to reach the students in a different way. Her husband is beginning to get worried. He does not understand why she is doing all this because clearly, no one has asked for it. Erin asks him to be patient because all these things are "temporary". Her sacrifices are not only in the matter of teaching her students with various ways so they finally can feel the difference and began to enjoy it, she even care for the personal matter of her students just like when Eva betrayed her Latin gang and gave an honest testimony in a court which caused Paco went to jail and her own people wanted to kill him for being a traitor and as the consequence she had to live with her auntie whose house is farther away from school and 
Erin sometimes offered her a ride home which made herself went home really late night. At the end all of her students gave respect she deserves.

c) Overcoming diversity is clearly seen in the movie as the main setting happened in the multicultural environment where different background of people are put together to adjust and adapt to each other.

Wilson High School in Long Beach, California where Erin teaches for the first time has students from different ethnics and backgrounds for they are immigrants who came to America for searching a better future. They are Cambodia, Ghetto or Negroid, Caucasian American and Hispanic or Latin America. In the beginning, each of these ethnics has their own zone, they sat and communicated based on their ethnic background as a gang inside and outside the class. To overcome this problem, during her class Erin moves the students around, change their sear out of their racial divisions. She attempts to show the students that they are united by playing the "Line Game" with them. She puts a line of thick red tape across the classroom and tells the students to move forward when a statement she makes applies to them. Her most effective form of reaching out, however, comes in the form of a black and white composition notebook. Since the school refuses to "waste" funds on these students, Erin has taken extra jobs in order to provide supplies for them. She gives each of the students a notebook and asks them to write in it every day. They can write in any form they wish, as long as it is continual. She tells them that it is completely private and she will not read their journals unless they put them into the locked cabinet in the back of the room. This teaching techniques are very effective to develop the understanding among these different ethnic background students and during 2 years Erin taught them, they can finally be united and honor each other differences.

d) Striving for success and trust message happens in the final plot where finally every sweat and tears were paid.

Success never comes in an easy way and that what happens to Erin Gruwell in her beginning career as a teacher in Room 203 Wilson High School in Long Beach, California where she assigned to teach very 
unique troublesome students who lived in a world of racial division, gang violence, drugs and broken homes. They were considered "unteachable" by other faculty members. With her own method and techniques in teaching, she attempts to teach these students despite their difficulties as well as the administration's reluctance to help her achieve this goal. Her struggle and efforts are not wasting at all, she finally can prove that her patience, persistence and skills in teaching can make her students reach their goal as much as she reaches hers as a good teacher. Here are some methods that Erin Gruwell used in teaching Room 203 Wilson High School like what is shown in the movie:

1) Giving some new books to students which have connection with their own daily life like The Diary of Anne Frank and Zlata's Diary: A Child's Life in Sarajevo, Homer's the Odessy etc and make them report them.

2) Using a song such as from the rapper Tupac Shakur to learn about rhyme and vocabularies.

3) Having a field trip to the Holocaust museum.

4) Using game for instance the "Line" game in developing the understanding among students in the classroom.

5) Conducting a free debate to increase students' speaking skills.

6) Assigning students to write their journal in notebook which then the compilation of those journals becomes well known as "Freedom Writers Diary" : a book which is used as one of the reading reference books in America.

\section{2 (a) Appraisal Devices Realizing Attitudes Used in Freedom Writers screenplay}

This part is aimed to break up the organization of the screenplay based on the point of view of Appraisal Device realizing Attitudes. It describes how the screenplay utilizes Affect, Judgment, and Appreciation that can reflect LaGravenes's feelings towards each character of the Freedom Writers. I classified the data that are categorized as Appraisal lexis by encoding them. They are: (1) Bold word for Affect such as the word love in "I'd love it if you'd look them over. (LaGravenese: 00:04:04,077 --> 00:04:06,637)" means that 
love belongs to an instance of Affect, (2) Underlined word for Judgment such as the word love in "He loves you. He just doesn't... (LaGravenese: 00:19:12,985 --> 00:19:14,316)" means that love belongs to the example of Judgment, (3) Bold and underlined word for Appreciation such as the word lovely in "I think you're a lovely, intelligent woman. (LaGravenese: 00:05:49,449 --> 00:05:53,579)" means that lovely belongs to the example of Appreciation.

Table 1. Summary of Attitudes towards the Main Characters

\begin{tabular}{|c|c|c|c|c|c|c|c|c|c|c|}
\hline & $\begin{array}{l}\text { Erin } \\
\text { Grumall }\end{array}$ & $\begin{array}{l}\text { Eya } \\
\text { Benite }\end{array}$ & & $\begin{array}{l}\text { Sindy } \\
\text { sigor }\end{array}$ & $\begin{array}{l}\text { Brandy } \\
\text { Ross }\end{array}$ & $\begin{array}{l}\text { Gloria } \\
\text { Mungy }\end{array}$ & Jamal Hill & Marcus & $\begin{array}{l}\text { Andre } \\
\text { Bryant }\end{array}$ & $\begin{array}{l}\text { Ben } \\
\text { Damiel }\end{array}$ \\
\hline $\begin{array}{l}\text { Total } \\
\text { Apporisal } \\
\text { Devices }\end{array}$ & 180 & 101 & & 3 & 6 & 4 & 19 & 43 & 19 & 14 \\
\hline Affact & 70 & 57 & & 1 & 1 & 2 & 7 & 20 & 7 & 5 \\
\hline Jucformant & 43 & 16 & & 2 & 5 & - & 1 & 8 & 2 & 1 \\
\hline Appreciation & 67 & 28 & & - & - & 2 & 11 & 15 & 10 & 8 \\
\hline & $\begin{array}{l}\text { Al-jamkiro } \\
\text { Santiggo }\end{array}$ & Tito & Mriguel & Yictoria & $\begin{array}{l}\text { Margaret } \\
\text { Campbell }\end{array}$ & $\begin{array}{l}\text { Briam } \\
\text { Golford }\end{array}$ & $\begin{array}{l}\text { Scott } \\
\text { Casay }\end{array}$ & $\begin{array}{l}\text { Steve } \\
\text { Grumell }\end{array}$ & $\begin{array}{l}\text { Miep } \\
\text { Gies }\end{array}$ & $\begin{array}{l}\text { DrCari } \\
\text { Cobsn }\end{array}$ \\
\hline $\begin{array}{l}\text { Total } \\
\text { Appraisal } \\
\text { Drvices }\end{array}$ & 1 & 3 & 21 & 21 & 59 & 25 & so & 21 & 21 & 9 \\
\hline Affect & - & 1 & 16 & 3 & 17 & 5 & 20 & 8 & 10 & 2 \\
\hline Judgmant & - & 1 & 1 & - & 14 & 8 & $\mathrm{~B}$ & 3 & 4 & 6 \\
\hline Appraciation & 1 & 1 & 4 & 18 & 28 & 12 & 22 & 10 & 7 & 1 \\
\hline
\end{tabular}

In the distribution of Affect, every chunk from each character in the movie was analyzed based on Emotional State, Physical Expression, Extraordinary Behavior and Metaphor. In table 4, it can be seen that as a leading character, Erin Gruwel dominated the distribution of Affect especially in the Emotional State. It means that LaGravenese emphasized on Erin's development character that she as the main protagonist emotionally involved and really gave her heart and soul to her students and her teaching job.

Table 2. Distribution of Affect

\begin{tabular}{|c|c|c|c|c|c|c|c|c|c|c|c|c|c|c|c|c|c|c|c|c|}
\hline \multirow[t]{3}{*}{ Character } & \multicolumn{4}{|c|}{ Emotional State } & \multicolumn{4}{|c|}{ Physical Expression } & \multicolumn{4}{|c|}{$\begin{array}{l}\text { Extracerdinary } \\
\text { Behavior }\end{array}$} & \multicolumn{4}{|c|}{ Metaphor } & \multicolumn{4}{|c|}{ Total Appraisal Devices } \\
\hline & \multicolumn{2}{|c|}{ Emoter } & \multicolumn{2}{|c|}{ Target } & \multicolumn{2}{|c|}{ Emoter } & \multicolumn{2}{|c|}{ Target } & \multicolumn{2}{|c|}{ Emoter } & \multicolumn{2}{|c|}{ Targat } & \multicolumn{2}{|c|}{ Emoter } & \multicolumn{2}{|c|}{ Target } & \multicolumn{2}{|c|}{ Emoter } & \multicolumn{2}{|c|}{ Target } \\
\hline & + & - & + & - & + & - & $\div$ & - & + & - & + & - & + & - & + & - & + & - & $\div$ & - \\
\hline $\begin{array}{l}\text { Erin } \\
\text { Grumell }\end{array}$ & 15 & 39 & 8 & 61 & - & - & - & - & 2 & 2 & 1 & 1 & 4 & 8 & 5 & 4 & 21 & 49 & 14 & 66 \\
\hline $\begin{array}{l}\text { Eva } \\
\text { Bonitez }\end{array}$ & 6 & 34 & - & 1 & - & - & - & - & 5 & 6 & 1 & - & 2 & 4 & 1 & 1 & 13 & 44 & 2 & 2 \\
\hline $\begin{array}{l}\text { Sindy } \\
\text { Nigor }\end{array}$ & - & 1 & - & - & - & - & - & - & - & - & - & - & - & - & - & - & - & 1 & - & - \\
\hline
\end{tabular}




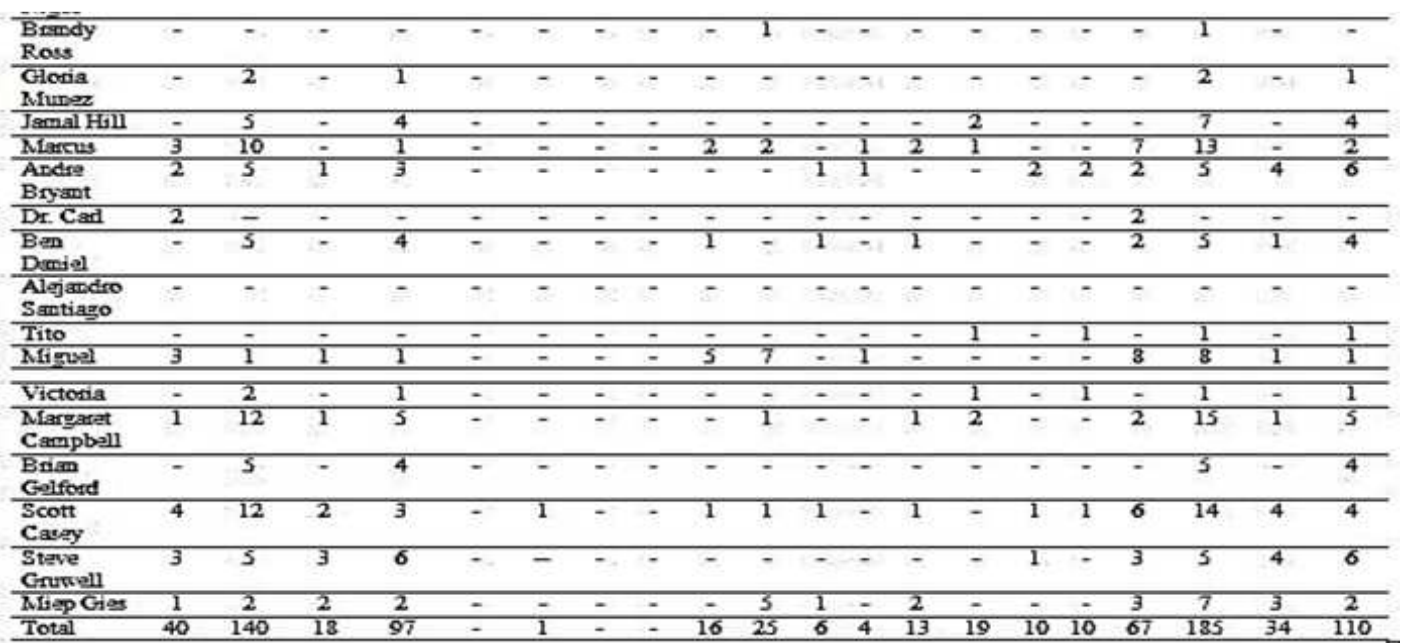

In the distribution of Judgment, the chunks analysis was divided into 5 criteria; Normality, Capacity, Tenacity, Veracity and Propriety. The tabulation in table 5 shows that Capacity expressions got the highest number of distribution.

Table 3. Distribution of Judgment

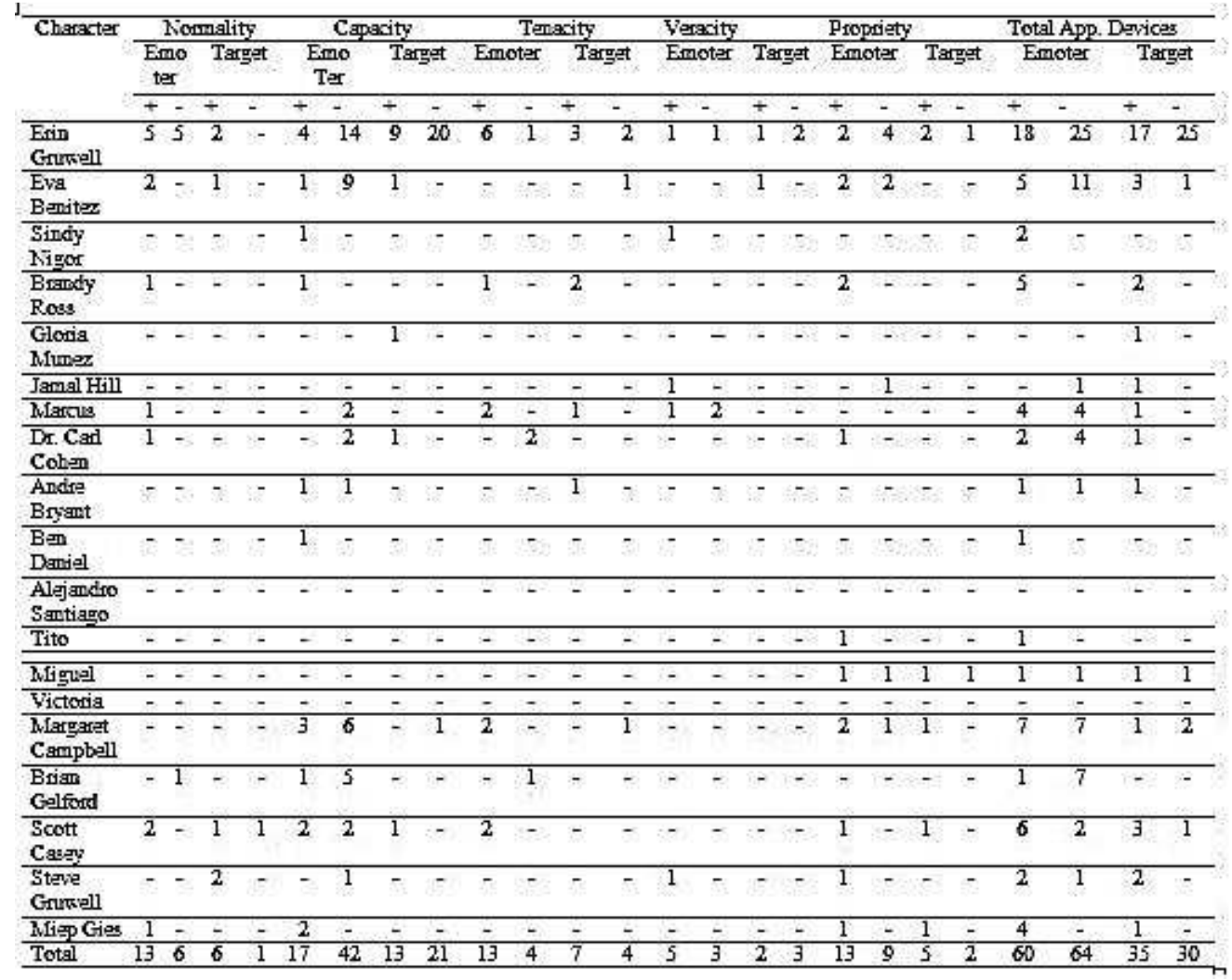

Similar to the distribution of Judgment, distribution of Appreciation was also divided into 5 criteria; Impact, Quality, Balance, Complexity and 
Valuation and it can be seen in table 6 that LaGravenese gave more portions to Impact expression than the others.

Table 4. Distribution of Appreciation

\begin{tabular}{|c|c|c|c|c|c|c|c|c|c|c|c|c|c|c|c|c|c|c|c|c|c|c|}
\hline \multirow[t]{3}{*}{ Character } & \multicolumn{4}{|c|}{ Impact } & \multicolumn{4}{|c|}{ Quality } & \multicolumn{4}{|c|}{ Balamoe } & \multicolumn{4}{|c|}{ Complexity } & \multicolumn{4}{|c|}{ Yaluation } & \multicolumn{2}{|c|}{$\begin{array}{l}\text { Total App. } \\
\text { Drvicess }\end{array}$} \\
\hline & \multicolumn{2}{|c|}{ Erroter } & \multicolumn{2}{|c|}{ Targat } & \multicolumn{2}{|c|}{ Emoter } & \multicolumn{2}{|c|}{ Targat } & \multicolumn{2}{|c|}{ Emoter } & \multicolumn{2}{|c|}{ Targat } & \multicolumn{2}{|c|}{ Ermoter } & \multicolumn{2}{|c|}{ Targat } & \multicolumn{2}{|c|}{ Emoter } & \multicolumn{2}{|c|}{ Targat } & $\begin{array}{c}\text { Esmo } \\
\text { ter }\end{array}$ & $\begin{array}{l}\text { Targe } \\
\mathrm{t}\end{array}$ \\
\hline & + & - & + & - & + & - & + & - & $\div$ & - & + & - & + & - & + & - & + & - & + & - & $+\quad-$ & +2 \\
\hline $\begin{array}{l}\text { Erin } \\
\text { Grumell }\end{array}$ & 16 & 10 & 5 & 11 & 9 & - & 4 & 1 & 1 & 4 & - & - & 5 & 8 & 3 & 4 & 9 & 5 & 8 & - & $40 \quad 27$ & $\begin{array}{ll}2 & 1 \\
0 & 6\end{array}$ \\
\hline $\begin{array}{l}\text { Eva } \\
\text { Benitex }\end{array}$ & 2 & 6 & 2 & 5 & - & - & - & - & 2 & 2 & - & - & 1 & 1 & - & I & 5 & 9 & 1 & - & 10 & 3 \\
\hline $\begin{array}{l}\text { Sindy } \\
\text { Nigor }\end{array}$ & - & - & - & - & - & - & - & - & - & - & - & - & - & - & - & - & - & - & - & - & - & - \\
\hline $\begin{array}{l}\text { Brandy } \\
\text { Ross }\end{array}$ & - & - & - & - & - & - & - & - & - & - & - & - & - & - & - & - & - & - & - & - & - & - \\
\hline $\begin{array}{l}\text { Gloria } \\
\text { Munex }\end{array}$ & - & 1 & - & 1 & - & - & - & - & - & 1 & - & 1 & - & - & - & - & - & - & - & - & 2 & - \\
\hline Jamal Hill & - & 3 & - & 2 & 1 & 2 & - & 2 & - & - & - & - & - & - & - & - & - & 5 & - & - & 10 & - \\
\hline Mlarcus & 3 & 5 & - & 1 & - & - & - & - & - & - & - & - & 2 & 1 & - & - & 1 & 3 & - & - & 9 & - \\
\hline $\begin{array}{l}\text { Andre } \\
\text { Bryant }\end{array}$ & - & - & - & 1 & - & 3 & 1 & 1 & - & - & - & - & - & - & 1 & - & 2 & 5 & - & - & 2 & 2 \\
\hline $\begin{array}{l}\text { Ben } \\
\text { Damiel }\end{array}$ & $=$ & 1 & - & 2 & 1 & - & - & - & - & - & - & - & - & 1 & - & - & 3 & 2 & - & - & 4 & - \\
\hline $\begin{array}{l}\text { Alejandiro } \\
\text { Santiago }\end{array}$ & - & - & - & - & - & - & - & - & - & - & - & - & 1 & - & - & - & - & - & - & - & 1 & - \\
\hline Tito & $=$ & - & - & - & 1 & - & - & - & $=$ & - & - & - & - & - & - & - & - & - & - & $=$ & 1 & - \\
\hline Migrol & 1 & - & - & - & - & - & - & - & 1 & - & 1 & - & - & - & - & $\overline{-}$ & 1 & 1 & 1 & & 3 & 2 \\
\hline Victoria & - & 1 & - & 1 & 3 & - & 3 & - & - & - & - & - & 1 & 2 & - & - & 2 & 9 & - & - & 12 & 3 \\
\hline $\begin{array}{l}\text { Mlargaret } \\
\text { Campbell }\end{array}$ & 1 & 3 & 1 & 1 & 6 & 1 & - & - & - & - & - & - & 4 & 4 & - & - & 6 & 3 & 1 & - & 17 & 2 \\
\hline $\begin{array}{l}\text { Briam } \\
\text { Gelford }\end{array}$ & - & 1 & - & - & 5 & - & - & - & - & - & - & - & 1 & 1 & - & - & 1 & 3 & 1 & - & 7 & 1 \\
\hline $\begin{array}{l}\text { Scott } \\
\text { Caagy }\end{array}$ & 4 & 3 & - & I & 4 & 2 & 1 & 1 & 1 & - & 2 & - & - & 2 & - & 1 & 5 & 1 & I & - & 14 & 43 \\
\hline $\begin{array}{l}\text { Steve } \\
\text { Grumall }\end{array}$ & 2 & - & - & 1 & 2 & - & - & 1 & - & - & - & - & - & 1 & - & - & 3 & 2 & - & - & 3 & -2 \\
\hline MEis Gies & I & - & - & - & - & - & - & - & 1 & 1 & - & - & - & - & - & 1 & 1 & 3 & I & - & 4 & 11 \\
\hline $\begin{array}{l}\mathrm{Dr} \text { Carl } \\
\text { Cobsy }\end{array}$ & - & 1 & 1 & - & - & - & - & - & - & - & - & - & - & - & $=$ & - & 1 & - & - & - & - & 11 \\
\hline Total & 30 & 35 & 9 & 27 & 32 & 8 & 9 & 6 & 6 & 8 & 3 & 1 & & 21 & 4 & 8 & 39 & 51 & 14 & - & $122 \quad 123$ & 3942 \\
\hline
\end{tabular}

The result shows that in Attitude the dominant result appears in Negative Emotional State where it takes 140 chunks from the total number of 185 negative Affect which mostly done by Erin Gruwell. This makes the Negative Emotional State gains $75,68 \%$ for the distribution of Affect. For the Judgment part, Negative Capacity reaches 65,63\% in which there are 42 chunks detected from the total 64 negative emoters, and for the last Appreciation part, Negative Valuation has the highest percentage: $41,46 \%$ for there are 51 chunks tabulated from the total 123 negative emoter chunks. The use of more Affect $(75,68 \%)$ in the screenplay indicates that LaGravenese emphasizes on character's emotion. 


\section{2 (b) Appraisal Devices Realizing Engagement Used in Freedom Writers screenplay}

Similar to what was done in analyzing the attitude, Martin and Rose's appraisal devices were also applied to analyze the engagement used in Freedom Writers screenplay. It describes how the screenplay utilizes Monogloss and Hetero-gloss that can reflect LaGravenes's points of view which are realized among characters in Freedom Writers and how he aligns himself with respect to the interpersonal position of each Freedom Writers' character. In identifying each engagement, I also classified the data that are categorized as Appraisal lexis by encoding them. They are: (1) Bold word for Hetero-gloss such as the word but in "My friends are soldier, not of war, but of the streets. (LaGravenese: 00:04:04,077 --> 00:04:06,637)" means that but belongs to an instance of Counter Expect, and (2) Underlined word for Mono-gloss such as "The city resembles a war zone. (LaGravenese: 00:00:54,654 --> 00:00:56,417)".

Table 5. Summary of Engagement towards the Main Characters

\begin{tabular}{|c|c|c|c|c|c|c|c|c|c|c|}
\hline & $\begin{array}{l}\text { Erin } \\
\text { Grumell }\end{array}$ & $\begin{array}{l}\text { Eva } \\
\text { Bemitez }\end{array}$ & $\begin{array}{l}\text { Sindy } \\
\text { Nigor }\end{array}$ & $\begin{array}{l}\text { Brandy } \\
\text { Ross }\end{array}$ & $\begin{array}{l}\text { Gloris } \\
\text { Mlumez }\end{array}$ & $\operatorname{Jam}$ & Fill & Marcus & $\begin{array}{l}\text { Andre } \\
\text { Bryent }\end{array}$ & $\begin{array}{l}\text { Ben } \\
\text { Daniel }\end{array}$ \\
\hline $\begin{array}{l}\text { Total } \\
\text { Appraizal } \\
\text { Drvices }\end{array}$ & 86 & 24 & 1 & 4 & 4 & & & 13 & 5 & 2 \\
\hline Heterogloss & 86 & 20 & 1 & 4 & 4 & & 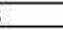 & 13 & 3 & 2 \\
\hline Mrong gloss & 10 & 4 & - & - & - & & E & - & 2 & - \\
\hline & $\begin{array}{l}\text { Alejandiro } \\
\text { Santiago }\end{array}$ & Tito & Migusal & Yictoria & $\begin{array}{l}\text { Margaret } \\
\text { Campbell }\end{array}$ & $\begin{array}{l}\text { Briam } \\
\text { Golford }\end{array}$ & $\begin{array}{l}\text { Scott } \\
\text { Casay }\end{array}$ & $\begin{array}{l}\text { Steve } \\
\text { Grumeall }\end{array}$ & $\begin{array}{l}\text { Miep } \\
\text { Gies }\end{array}$ & $\begin{array}{l}\mathrm{Dr} \\
\mathrm{Carl} C\end{array}$ \\
\hline $\begin{array}{l}\text { Total } \\
\text { Appraisal } \\
\text { Devices }\end{array}$ & - & 2 & 8 & 7 & 19 & 5 & 22 & 5 & 5 & 5 \\
\hline Hetrogloses & - & 2 & 8 & 6 & 19 & 5 & 22 & 5 & 8 & 5 \\
\hline Monogloss & - & - & - & 1 & - & - & - & - & - & - \\
\hline
\end{tabular}

Engagement deals with Hetero-gloss and Mono-gloss expressions. In a general movie term, hetero-gloss means dialogue and mono-gloss refers to monologue. 
Table 6. Distribution of Hetero-gloss

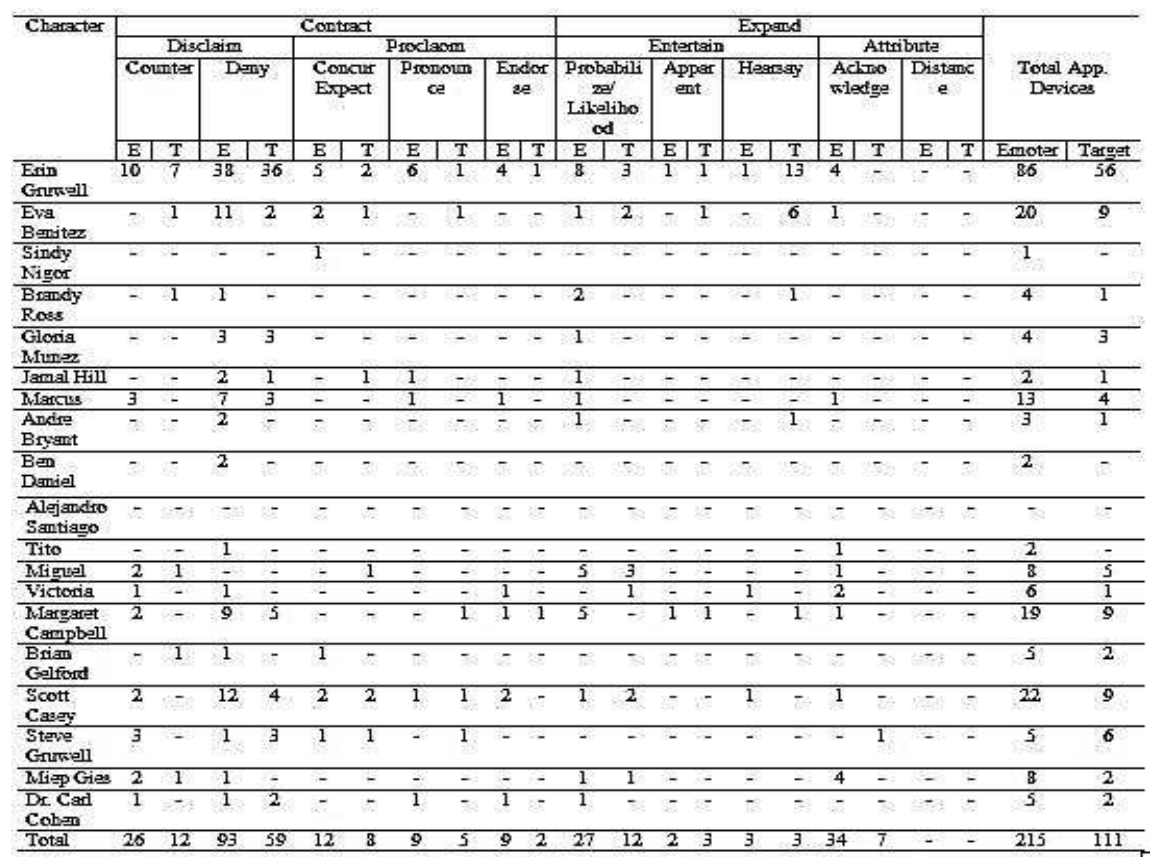

In every movie, there must be dialogues and monologues to develop the story. In Freedom Writers movie, LaGravenese distributed more dialogues than monologues which can be seen in table 6 and table 7 .

Table 7. Distribution of Mono-gloss

\begin{tabular}{|c|c|c|}
\hline Charater & Morogloss & Total \\
\hline $\begin{array}{l}\text { Erin } \\
\text { Grumell }\end{array}$ & 10 & 10 \\
\hline $\begin{array}{l}\text { Eva } \\
\text { Beniterz }\end{array}$ & 5 & 5 \\
\hline $\begin{array}{l}\text { Sindy } \\
\text { Nigor }\end{array}$ & - & - \\
\hline $\begin{array}{l}\text { Brandy } \\
\text { Rose }\end{array}$ & 3 & 3 \\
\hline $\begin{array}{l}\text { Glowia } \\
\text { Mlurox }\end{array}$ & - & - \\
\hline Jamal Hill & - & - \\
\hline Marcus & 4 & 4 \\
\hline $\begin{array}{l}\text { Andire } \\
\text { Bryant }\end{array}$ & 4 & 4 \\
\hline $\begin{array}{l}\text { Ben } \\
\text { Daniol }\end{array}$ & - & - \\
\hline $\begin{array}{l}\text { Alfijandiro } \\
\text { Sartiago }\end{array}$ & - & - \\
\hline Tito & - & - \\
\hline Migulel & - & - \\
\hline Yictoria & - & - \\
\hline $\begin{array}{l}\text { Margaret } \\
\text { Camposll }\end{array}$ & - & - \\
\hline $\begin{array}{l}\text { Brim } \\
\text { Gilford }\end{array}$ & - & - \\
\hline $\begin{array}{l}\text { Scott } \\
\text { Casay }\end{array}$ & - & - \\
\hline $\begin{array}{l}\text { Stave } \\
\text { Gurwall }\end{array}$ & - & - \\
\hline Miep Gies & - & - \\
\hline $\begin{array}{l}\text { DrCard } \\
\text { Cobsm }\end{array}$ & - & - \\
\hline Tota & & \\
\hline
\end{tabular}

In Distribution of Engagement table, the Denial Disclaim appears $43,26 \%$ dominantly for the distribution of Hetero-gloss in which 93 chunks 
were found from the total of 215 emoter chunks while Mono-gloss only takes minimal part in it. The use of more Disclaim hetero-gloss $(43,26 \%)$ in the screenplay indicates that LaGravenese emphasizes on character's subjectivity. Since the movie is based on a true story, Richard LaGravene made the screenplay as close as possible to the real story by conducting interview, observation and survey before he wrote it. A lot of dialogue interactions reflected his screenplay really pictures the actual event even though his interpersonal point of view affected on how he developed each of the character in every stage of the movie narrative structures.

\section{2 (c) Appraisal Devices Realizing Graduation Used in Freedom Writers screenplay}

Martin and Rose's appraisal devices were also used to analyze the Freedom Writers screenplay's graduation aspect. It describes how the screenplay utilizes Force and Focus that can reflect LaGravenes's values which act to provide grading or scaling, either in terms of the interpersonal force which the Freedom Writers' characters attach to an utterance or in terms of the preciseness or sharpness of focus with which an item exemplifies a velour relationship among characters in Freedom Writers. In identifying each graduation, I also classified the data that are categorized as Appraisal lexis by encoding them. They are: (1) Bold word for Force such as the word really in "I am, and I really want to be here. (LaGravenese: 00:06:06,799 --> 00:06:10,693)" means that really belongs to an instance of Explicit force, and (2) Bold and underlined word for Focus such as "I think the real fighting should happen here in the classroom. (LaGravenese: 00:05:33,232 --> 00:05:36,861)". The word real belongs to an instance of Sharpen focus.

Table 8. Summary of Graduation towards the Main Characters

\begin{tabular}{|c|c|c|c|c|c|c|c|c|c|c|}
\hline & $\begin{array}{l}\text { Erin } \\
\text { Grumell }\end{array}$ & $\begin{array}{l}\text { Eva } \\
\text { Benitgz }\end{array}$ & $\begin{array}{l}\text { Sirdy } \\
\text { Nigor }\end{array}$ & $\begin{array}{l}\text { Bramdy } \\
\text { Ross }\end{array}$ & $\begin{array}{l}\text { Gloria } \\
\text { Mungz }\end{array}$ & Jamal Hill & Mlarcus & $\begin{array}{l}\text { Andre: } \\
\text { Bryant }\end{array}$ & $\begin{array}{l}\text { Ban } \\
\text { Dan: }\end{array}$ & \\
\hline $\begin{array}{l}\text { Total } \\
\text { Appraisal } \\
\text { Devices }\end{array}$ & 97 & 22 & 2 & 2 & 2 & 8 & 19 & 11 & & 4 \\
\hline Force & 41 & 6 & - & - & 1 & 4 & 6 & 2 & & - \\
\hline \multirow[t]{2}{*}{ Fonss } & 56 & 16 & 2 & 2 & 1 & 4 & 13 & 9 & & 4 \\
\hline & $\begin{array}{l}\text { Alejandiro } \\
\text { Santigaro }\end{array}$ & Tito & Miguel & Yictoria & $\begin{array}{l}\text { Margaret } \\
\text { Campbell }\end{array}$ & $\begin{array}{l}\text { Briam } \\
\text { Golford }\end{array}$ & $\begin{array}{l}\text { Scott } \\
\text { Casay }\end{array}$ & $\begin{array}{l}\text { Steve } \\
\text { Grumall }\end{array}$ & $\begin{array}{l}\text { Misp } \\
\text { Gies }\end{array}$ & $\begin{array}{l}\text { Dr. } \\
\text { Card }\end{array}$ \\
\hline $\begin{array}{l}\text { Total } \\
\text { Appraisal } \\
\text { Drvices }\end{array}$ & 2 & 2 & 19 & 8 & 29 & 16 & 24 & 5 & 8 & 7 \\
\hline Force & 1 & 1 & 13 & - & 12 & 6 & 10 & 3 & 1 & 3 \\
\hline Fonts & 1 & 1 & 6 & 8 & 17 & 10 & 14 & 2 & 7 & 4 \\
\hline
\end{tabular}


It can be seen in table 8 that Graduation deals with Force and Focus.

Table 9. Distribution of Force

\begin{tabular}{|c|c|c|c|c|c|c|c|c|c|c|}
\hline \multirow[t]{3}{*}{ Character } & \multicolumn{4}{|c|}{ Implicit } & \multicolumn{4}{|c|}{ Explicit } & \multirow{2}{*}{\multicolumn{2}{|c|}{$\begin{array}{c}\text { Total App. } \\
\text { Devices }\end{array}$}} \\
\hline & \multicolumn{2}{|c|}{ Raise } & \multicolumn{2}{|c|}{ Loker } & \multicolumn{2}{|c|}{ Rsisa } & \multicolumn{2}{|c|}{ Lower } & & \\
\hline & Emoter & Targyt & Emoter & Targit & Emoter & Target & Emoter & Targat & Emoter & Targyt \\
\hline $\begin{array}{l}\text { Erin } \\
\text { Grumell }\end{array}$ & 6 & - & - & 3 & 27 & 11 & 8 & 9 & 41 & 23 \\
\hline $\begin{array}{l}\text { Eva } \\
\text { Benitez }\end{array}$ & 1 & - & - & - & 1 & 1 & 4 & - & 8 & 1 \\
\hline $\begin{array}{l}\text { Sindy } \\
\text { Nigor }\end{array}$ & - & - & - & - & - & - & - & - & - & - \\
\hline $\begin{array}{l}\text { Brandy } \\
\text { Ross }\end{array}$ & -7 & - & - & - & - & 1 & - & - & - & 1 \\
\hline $\begin{array}{l}\text { Gloria } \\
\text { Munes }\end{array}$ & - & 1 & - & - & 1 & - & - & - & 1 & 1 \\
\hline Jamal Hill & - & - & 4 & - & - & - & - & - & 4 & - \\
\hline Marcess & 2 & - & 1 & 1 & 2 & 2 & 1 & - & 8 & 3 \\
\hline $\begin{array}{l}\text { Andie } \\
\text { Bryant }\end{array}$ & - & - & 1 & 2 & 1 & - & - & - & 2 & 2 \\
\hline $\begin{array}{l}\text { Ban } \\
\text { Danijel }\end{array}$ & - & - & - & - & - & - & - & - & - & - \\
\hline $\begin{array}{l}\text { Alejandio } \\
\text { Santigero }\end{array}$ & - & - & - & - & 1 & - & - & - & 1 & - \\
\hline Tito & $\begin{array}{ll}- \\
-\end{array}$ & - & - & - & 1 & - & - & - & 1 & - \\
\hline Miginol & 2 & - & - & - & 6 & 1 & 5 & 3 & 13 & 4 \\
\hline Fictoria & - & - & - & - & - & 1 & - & - & - & 1 \\
\hline Mirgaret & - & - & - & - & 12 & - & - & 2 & 12 & 2 \\
\hline Campboll & & & & & & & & & & \\
\hline $\begin{array}{l}\text { Briam } \\
\text { Golford }\end{array}$ & - & - & 1 & - & 2 & 1 & 3 & 1 & 6 & 2 \\
\hline $\begin{array}{l}\text { Scott } \\
\text { Caagy }\end{array}$ & 1 & 1 & - & - & 3 & 2 & 6 & 1 & 10 & 4 \\
\hline $\begin{array}{l}\text { Steve } \\
\text { Grumeall }\end{array}$ & - & - & - & - & 2 & 2 & 1 & - & 3 & 2 \\
\hline Mimp Gias & - & - & - & & 1 & & - & - & 1 & - \\
\hline $\begin{array}{l}\text { Dr. Carl } \\
\text { Cobsm }\end{array}$ & - & - & - & - & 2 & 2 & 1 & - & 3 & 2 \\
\hline Total & 12 & 2 & 7 & 6 & 62 & 24 & 29 & 13 & 110 & 48 \\
\hline
\end{tabular}

Table 9. Distribution of Force was tabulated under 2 criteria: Implicit and Explicit Force which were then divided again into Raise and Lower Implicit and Raise and Lower Explicit. Similar to Force, there are also 2 criteria analysis for table 10. Distribution of Focus; Sharpen and Soften.

Table 10. Distribution of Focus

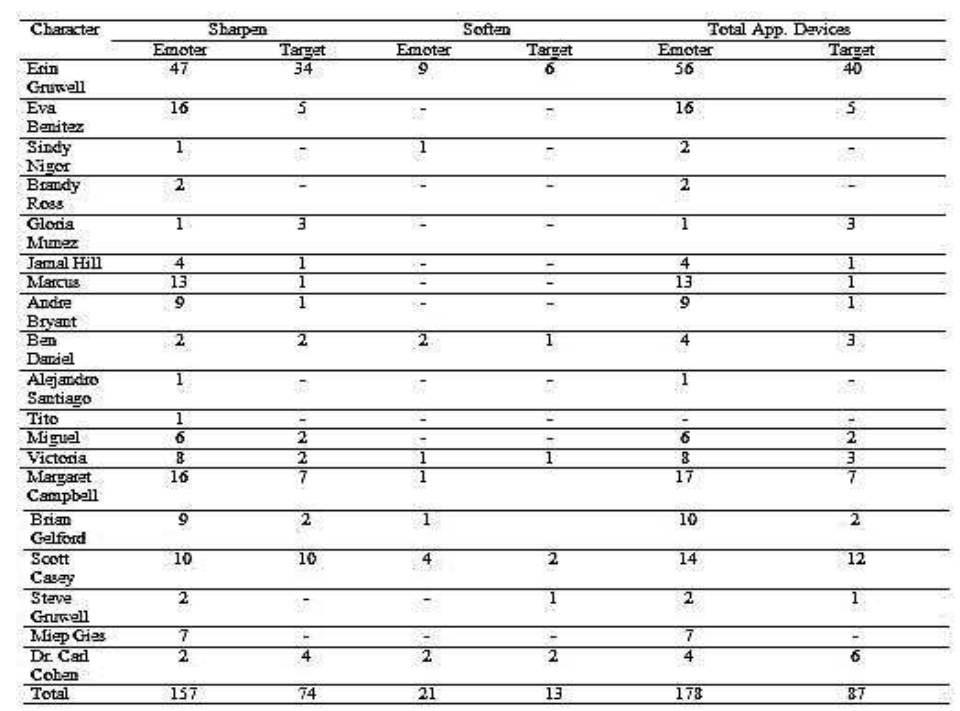


Graduation result shows that Explicit Raise got $56,36 \%$ for the distribution of Force and it reaches higher than the others for there were 62 chunks found from the total of 110 emoter chunks. The last, for the distribution of Focus, Sharpen Expression appears 88,20\% dominantly than Soften Expression with the comparison of 157 sharpen emoter chunks to 21 soften emoter chunks. The use of more sharpening focus $(88,20 \%)$ in the screenplay indicates that LaGravenese emphasizes on character's category boundary.

\section{CONCLUSION}

The conclusion reveals that (1) there are several messages found in Freedom Writers movie from the realization of Appraisal Stylistic System either in the dialogues or monologues of Freedom Writers' characters. Through good diction, LaGravenese gives the messages of tolerance, earning respect and trust, honor diversity, and striving for success and trust. It also shows (2) the Appraisal Devices realizing (2a) Attitudes used in Freedom Writers movie are: LaGravenese likes to express characters' negative emotion explicitly than implicitly. He likes to express characters' negative capability than other kinds of Judgments. He appreciates the characters using more Negative Value which denotes that in his opinion, they see each other negatively. (2b) Engagement used in the screenplay describes that he emphasizes more on characters' denial towards each other's opinion and existence with the use of more Disclaim Hetero-gloss in the screenplay. (2c) Graduation used in the screenplay describes that the use of more Sharpening Focus indicates he emphasizes on characters' category boundary more than scaling of intensity.

\section{REFERENCES}

James Paul Gee and Michael Handford. (2012). The routledge handbook of discourse analysis. Available at: http://english.iaukhomein.ac.ir/Files/ 26/Content/(Routledge\%20handbooks\%20in\%20applied\%20linguistics) \%20James\%20Paul\%20Gee_\%20Michael\%20Handford-The\%20 Routled 
ge\%20handbook\%20of\%20discourse\%20analysis-Routledge\%20 (2012). pdf (accessed 31/05/2014)

Halliday, M.A.K. (1994). An introduction to functional grammar. London: Edward Arnold.

Halliday, M.A.K. and R. Hasan. (1985). Language, context, and text: aspects of language in a social semiotic perspective. Melbourne: Deakin University Press.

Martin, J.R. and D. Rose. (2003). Working with discourse; meaning beyond the clause. Sydney: Copyright JR Martin and David Rose.

Matthiessen, C. (1995). Lexicogrammatical cartography. Tokyo: International Language Sciences Publisher.

Paramount Picture. (2006). Freedom writers movie's transcript available at: http://www.script-o-rama.com/freedom-writers-transcript.htm/

Stubbs, M. (1987). Discourse analysis. Oxford: Blackwell Ltd.

Teaching English Organization. (2011). Literacy chunk available at: htt://www.teachingenglish.org.uk/think/...wiki/lexical-chunk

White, P.R.R. (2002). Appraisal; the Language of Evaluation and Stance. In The handbook of pragmatics. Versch mmn J, et al, (eds). Amsterdam/ Philadelphia: John Benjamins Publishing Co. P. 1-27. Available at: http:/ / homepage.mac.com/philchappell/public/PwhiteAppraisal(prag's ).pdf) (accessed 12/6/2014)

White, P.R.R. (2001a). Appraisal: An overview. Available at: http://www. grammatics. com/appraisal/AppraisalGuide/Appraisal-Overview.doc. (accessed 12/6/2010).

White, P.R.R. (2001b). Affect. Available at: http://www.grammatics.com/ appraisal/ appraisalGuide/StageI-attitude-Affect.doc). (accessed 12/6/ 2014).

White, P.R.R. (2001c). Judgment. Available at: http://www.grammatics.com/ appraisal/ appraisalGuide/Stage2-attitude-Judgement.doc). (accessed 12/6/2014). 
Hidayati, Appraisal Analysis In Freedom Writers Movie

White, P.R.R. (2001d). Appreciation. Available at: http://www.grammatics .com /app raisal / appraisalGuide / Stage3 - attitude - Apprecation . doc) . (accessed 12/6/2014).

White, P.R.R. (2001e). Intertextuality. Available at: http://www.grammatics. com/ appraisal / appraisalGuide / Stage4-Intertextuality.doc).(accessed 12/6/20104). 